\title{
Social and Economic Impact of Drought on Stakeholders in Agriculture
}

\author{
Tanja Armenski ${ }^{*}$, Uglješa Stankov ${ }^{A}$, Dragan Dolinaj ${ }^{A}$, Minučer MesarošA, Mlađen JovanovićA, \\ Milana Pantelić ${ }^{A}$, Dragoslav Pavić ${ }^{A}$, Srđan Popov ${ }^{B}$, Ljiljana Popović ${ }^{B}$, Ana Frank ${ }^{B}$, Đorđe Ćosić ${ }^{B}$
}

Received: July 9, 2014 | Revised: July 21, 2014 | Accepted: August 1, 2014

\begin{abstract}
According to different relevant climate research water shortage hazard become increasingly frequent natural hazard across Serbia. In Serbia, especially in Vojvodina, drought is a natural hazard with increasing frequency of occurrence. Vojvodina is predominantly agricultural area with $11 \%$ of agricultural population. As such agricultural population is highy sensitive to natural hazards, especially to occurrence of drought which is typical for the territory of Vojvodina. Drought has influence on the environment and human activities, i.e. it has social and economic consequences, such as drinking water shortage or decline in crop yield.
\end{abstract}

Therefore this paper has several aims. First goal is to explore socio demographic profiles and agricultural characteristic of agricultural population and stakeholders in research area. Secondly to examine farmers' attitudes to possible damage prevention and adaptive measures to climate change in the sector of agricultural production. Third goal is to analyze respondent's opinion toward drought prediction. Finally the study examines opinion of respondents on the role of government institutions in providing assistance and support to farmers and to agricultural development in the region.

In depth semi structural interviewing were carried out.

Results show lack of knowledge among respondents that water shortage can be precisely and in time predicted to help agriculture prepare and prevent possible draft damages. As the main problems in agriculture, the local agricultural population lists absence of strategic planning and management of agrarian policy, as well as absence of state support to farmers in agriculture development.

Necessary assistance for alleviation of adverse drought consequences includes subsidies for irrigation, improvement and reconstruction of the existing irrigation systems; organized and planned state management of agrarian policy; creating precise methods of forecast of drought periods and timely informing agricultural population and agricultural firms.

Key words: Vojvodina, Water Shortage Hazard, Social and Economic Impact, Agriculture

A Department of Geography, Tourism and Hotel Management, Faculty of Sciences, University of Novi Sad, Trg Dositeja Obradovića 3, 21000 Novi Sad, Serbia

B Disaster Risk Reduction Research Center, Faculty of Technical Sciences, University of Novi Sad; Trg Dositeja Obradovića 6, 21000 Novi Sad, Serbia

* Corresponding author: Tanja Armenski, e-mail: tanjaarama@yahoo.com 


\section{Introduction}

Water is a resource which is critical to the survival, integrity and wellbeing of humans and the environment. However, the availability of fresh water supplies is becoming increasingly scarce, and is projected to intensify in the future (Hurlimann, Dolnicar, 2011). In the past, settlements have been abandoned due to water scarcity (Wilhite, 2005). Soil water is an integral part of the hydrologic cycle and a critical parameter for plant growth and development. Dale and Shaw (1965) reported that soil water is one of the most critical factors for crop development and yield.

Drought is a natural hazard caused by the variability in climate, which cannot be prevented. However, its effects can be reduced through management systems incorporating drought monitoring. Monitoring the relevant hydro-meteorological parameters and creation of suitable forecast tools within a hydro-information system for monitoring drought warning would serve as a platform for decision making in drought effects reduction (Gocić, Trajković, 2012). Drought is a natural, recurring phenomena that occurs everywhere at various points in time and is occurring somewhere on Earth at any given point of time. Drought can be defined as the result of a shortage of precipitation that limits plant water availability to such an extent that ecosystem productivity is reduced. In the specific case of agricultural areas this can lead to yield reductions implying in some cases important economic consequences (Nikolova et al., 2012; Sepulcre-Canto, et al., 2014). Drought is a complex topic with ecosystem impacts that vary with its intensity and duration and socioeconomic impacts that often magnify problems for the most vulnerable members of society. Perhaps it is fitting that drought does not have a universal definition and is often considered in the context of four broad categories defined by Wilhite and Glantz (1985): meteorological, agricultural, hydrological, and socioeconomic.

\section{Literature review}

In the literature we often encounter in short-term drought. Short-term drought, sometimes referred to as flash drought, is a rapid onset of drought often accompanied by high temperatures and winds that lead to rapid soil moisture depletion during a critical time in the growing season (Svoboda et al., 2002). Flash droughts can occur within a longer period of normal or above normal precipitation and bring devastating agricultural impacts (Hunt, et al., 2014).

Drought impacts on plants differ with endogenous factors (e.g. stomatal size and density, root structures or plant height) and with environmental conditions (e.g. air and soil temperature, air humidity and pho- tosynthetically active radiation) (Bollig, Feller, 2014). Drought is occurring more frequently in arid and semi-arid regions of the world. Global climate change is also increasing both its extent and intensity (IPCC, 2010). Critical features of drought and its impact on resource-dependent sectors, such as agriculture, raise concern about meeting the demands for water and food (Karami, Keshavarz, 2009). Appropriate drought management policies are needed to alleviate negative consequences (O'Brien et al., 2006) and increase the capacity of varying societies to adapt successfully (Næss, et al., 2005). Rural communities and organizations, embedded in the natural environment (Starik, Rands, 1995), must learn how to increase their capacity to adapt to drought conditions. However the covariate nature and frequency of droughts (Keshavarz, et al., 2013) make efficient management difficult. Human suffering, natural resources degradation, and shortages of credit force organizations to act more responsibly in reducing the drought vulnerability, and managing the impact of the drought on rural societies. A comprehensive, adaptive system is therefore imperative (Comfort, Kapucu, 2004) to respond to the pressures and develop mechanisms for reducing negative consequences. Meeting such challenges requires increased and proactive organizational performance (Holbeche, 2006). Organizations must avoid focusing narrowly on drought management outputs and pay more attention to the operating processes (Wilbanks, 2002) at different levels. Institutional adaptation refers to the creation of an effective, longterm government institution or set of institutions in charge of planning and policy, and its capacity to develop, revise, and execute drought policies (Keshavarz, Karami, 2013).

Droughts are usually regional, covering a wider area, last longer than other hydrological extremes, therefore it is especially important to examine the regional context (Milanović, et al., 2012). In our country, the drought is not a regular occurrence although it is more common in Vojvodina (Mihailović, et al., 2000; Jovanović et al., 2013). Drought as a result of climate change in Vojvodina studied Bosnjak (1977, 1993, 1995, 1997, 2001), Vučić (1989), Dragović (1995), Mihailović, et al., (2000), Božić, et al. (2007), Rajić and Štula (2007), Ivanović, et al. (2008), Rajić and Grujić (2013).

Since 1988 the most serious damage caused by drought was registered in 1990, 1993, 2000, 2003, 2008 and 2012. In 1990 the damage was estimated at 875 million EUR (3.5\% of the total national income). In 1993 the damage was estimated at half a billion EUR. In 2003 this amounted to a figure of one billion EUR, only to be doubled in 2012 when the draught-related damage reached 2 billion EUR, out of which the damage was estimated at about one billion EUR in Vojvodina alone (Vojvodina Chamber of Commerce, 2012). 
Based on the abovementioned data it can be concluded that on the Vojvodina territory drought is the natural phenomenon causing most extensive damage to various industries and hindering undisturbed growth of agriculture. Therefore this study has several goals. First to examine attitudes of agricultural population and stakeholders in agriculture to the main issues in agriculture in the region. Second to examine farmers' attitudes to possibilities of prevention damage and adaptive measures to climate change in the sector of agricultural production. Third to research possibilities of prediction of drought occurrence and dry periods in order to create water management strategies and sustainable agricultural production. Finally the study deals with interviewing agricultural population and stakeholders in agriculture on the role of government institutions in providing assistance and support to farmers and to agricultural development of the region.

\section{Methods and data}

For the purpose of the research interviewing list was created with 53 open and semi-open questions. In order to keep research clear and comprehensive all questions in the questionnaire were divided into five sections. First section is related to research of socio demographic characteristics of the respondents (gender, age, education). Second part contains questions concerning characteristics of farmers and agriculture (experience in agriculture, size of agricultural land used by the farmer, soil fertility category, crops grown). Third part is related to occurrence of drought and consequences of drought periods. Fourth part deals with research of opinions on efficiency in water management in the research area and sustainability of agricultural production through adaptive strategies to climate changes. Fifth part looks into research of possibilities of prediction of occurrence of drought and drought periods as well as the role of government institutions in providing aid and support to farmers and agricultural development of the region in general. Targeted research area encompasses Vojvodina population gravitating to the research area of the IPA HUSRB project "Water shortage hazard and adaptive water management strategies in the Hungarian-Serbian cross-border region" (WAHASTRAT - HUSRB/1203/121/130) (Figure 1).

Targeted research population includes active farmers and agricultural businesses that are major stakeholders in agriculture in the area of research. Using convenient sampling method a total of 43 farmers and 7 representatives of agricultural businesses operating in the area of research were interviewed. The research was carried out at the end of 2013 and the beginning of 2014, by the method of structured in-depth interview. The interviewing technique enabled an in-depth insight into the issue because it enabled the respondents to express their views and opinions in more detail

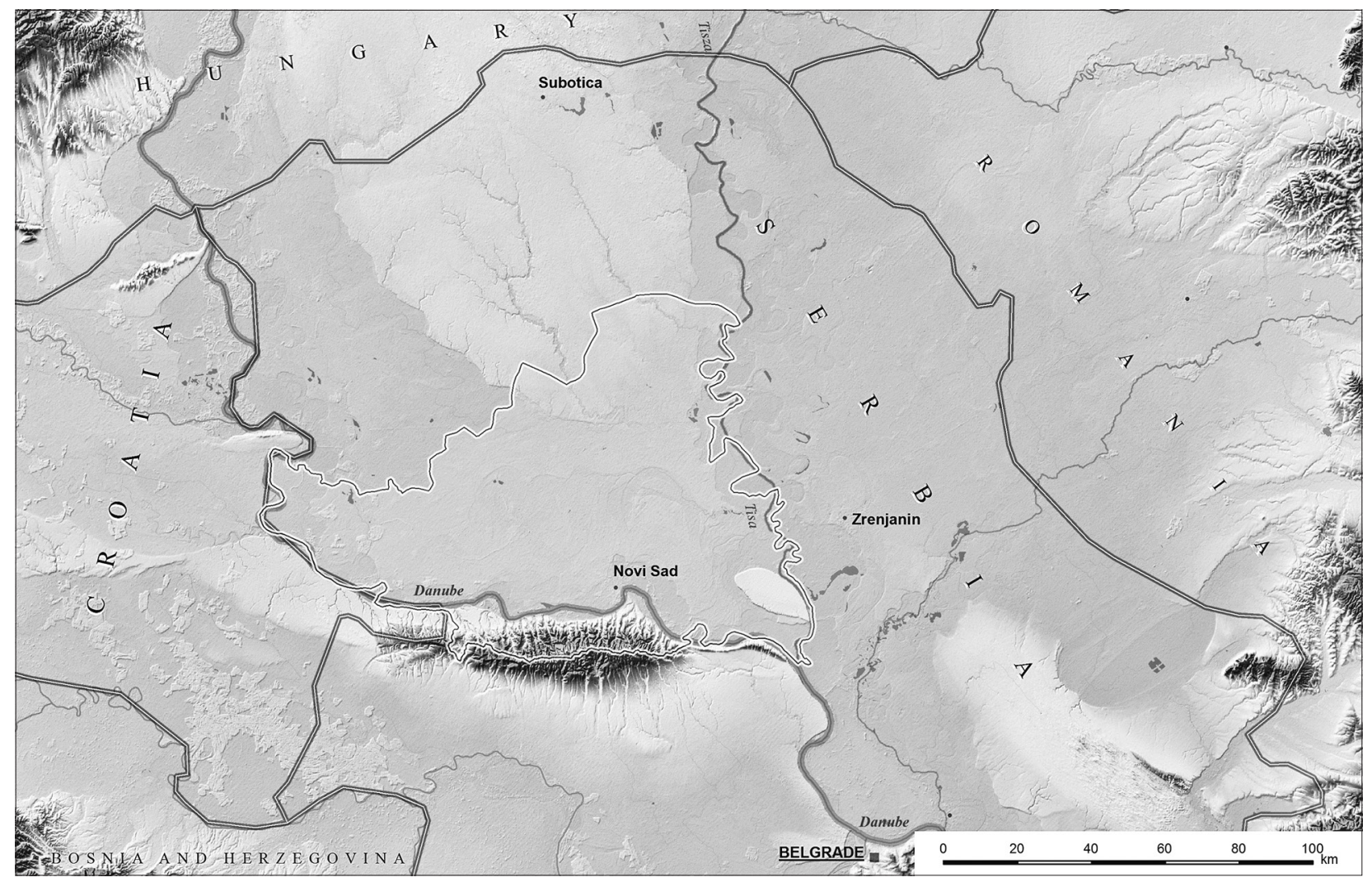

Figure 1. Research area 
Table 1. Socio demographic characteristics of the respondents

\begin{tabular}{|c|c|c|c|}
\hline \multicolumn{4}{|l|}{ FARMERS } \\
\hline $\begin{array}{l}\text { Gender: } \\
\text { Male } \\
\text { Female } \\
\text { Total }\end{array}$ & $\begin{array}{r}39 \\
4 \\
43\end{array}$ & $\begin{array}{l}\text { Education: } \\
\text { Primary school } \\
\text { Secondary school } \\
\text { Advanced school } \\
\text { Higher education (MSc/PhD) }\end{array}$ & $\begin{array}{r}16,3 \% \\
48,8 \% \\
16,3 \% \\
18,6 \%\end{array}$ \\
\hline $\begin{array}{l}\text { Age } \\
>35 \\
36-45 \\
46-55 \\
56>\end{array}$ & $\begin{array}{l}16,3 \% \\
39,5 \% \\
27,9 \% \\
16,3 \%\end{array}$ & $\begin{array}{l}\text { Status in relation to the agricultural household: } \\
\text { Lease holder } \\
\text { Owner } \\
\text { Other } \\
\text { Lease holder and owner }\end{array}$ & $\begin{array}{r}7 \% \\
46,5 \% \\
0 \% \\
46,5 \%\end{array}$ \\
\hline \multicolumn{4}{|c|}{ REPRESENTATIVES OF AGRICULTURAL BUSINESSES } \\
\hline $\begin{array}{l}\text { Education: } \\
\text { Primary school } \\
\text { Secondary school } \\
\text { Advanced school } \\
\text { Higher education (MSc/PhD) }\end{array}$ & $\begin{array}{r}0 \% \\
0 \% \\
57,1 \% \\
42,9 \%\end{array}$ & $\begin{array}{l}\text { Age } \\
>35 \\
36-45 \\
46-55 \\
56>\end{array}$ & $\begin{array}{r}42,9 \% \\
28,6 \% \\
14,3 \% \\
14,3 \%\end{array}$ \\
\hline $\begin{array}{l}\text { Status in relation to the agricultural business: } \\
\text { Lease holder } \\
\text { Owner } \\
\text { Other } \\
\text { Lease holder and owner }\end{array}$ & $\begin{array}{r}14,3 \% \\
28,6 \% \\
57,1 \% \\
0 \%\end{array}$ & & \\
\hline
\end{tabular}

Source: Authors research

avoiding influence from other respondents. Data collection was carried out by the method of telephone interview. Table 1 shows socio demographic characteristics of the respondents.

\section{Research results}

\section{Characteristics of agriculture and farmers}

An equal number of farmers are also land owners who lease additional agricultural land $(46.5 \%)$ or they are owners of an agricultural holding (46.5\%), while a few lease agricultural land ( $7 \%)$. As far as other stakeholders in agriculture are concerned, those are either legal entities or cooperatives. Farmers typically work on smaller agricultural plots of land with size ranging from 0.25 to 250 ha. Larger agricultural farms are in hands of stakeholders in agriculture whose plots of land range from 300 to 1570 ha. Majority of the respondents own agricultural farms on the territories of Srbobran, Čenej, Kać, Kovilj, Bečej, Begeč, Despotovo and Đurđevo (Figure 2).

Local farmers mainly work on land of 1st and 2nd soil fertility category. In the research area the following crops are predominantly grown: corn, soy, wheat, sugar beet, and sunflower. On smaller plots vegetables are mainly grown: potato, cabbage, onion, pepper, and carrot. As for work experience in agriculture, almost all farmers have more than 7 years of experience (97.7\%), while the agricultural firms have operated for more than 6 years in $80 \%$ of the cases.
As the main problems in agriculture, the local agricultural population lack strategic planning and management of agrarian policy, as well as absence of state support to farmers in agriculture development. The respondents very often mentioned generally inadequate financial policy, primarily concerning high costs of agricultural production, uncertain market placement of agricultural produce, and low prices of purchase. Absence of adequate irrigation systems, as well as the fact that the existing ones are obsolete and not maintained, is stated as a serious agriculture-related problem in the region. A few respondents listed frequent occurrence of natural hazards (drought,

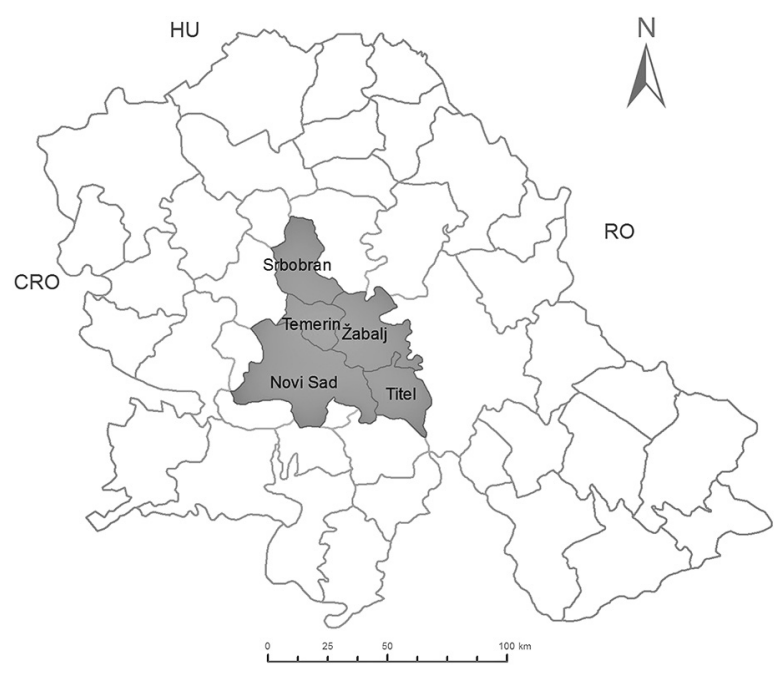

Figure 2. Respondents' locations 


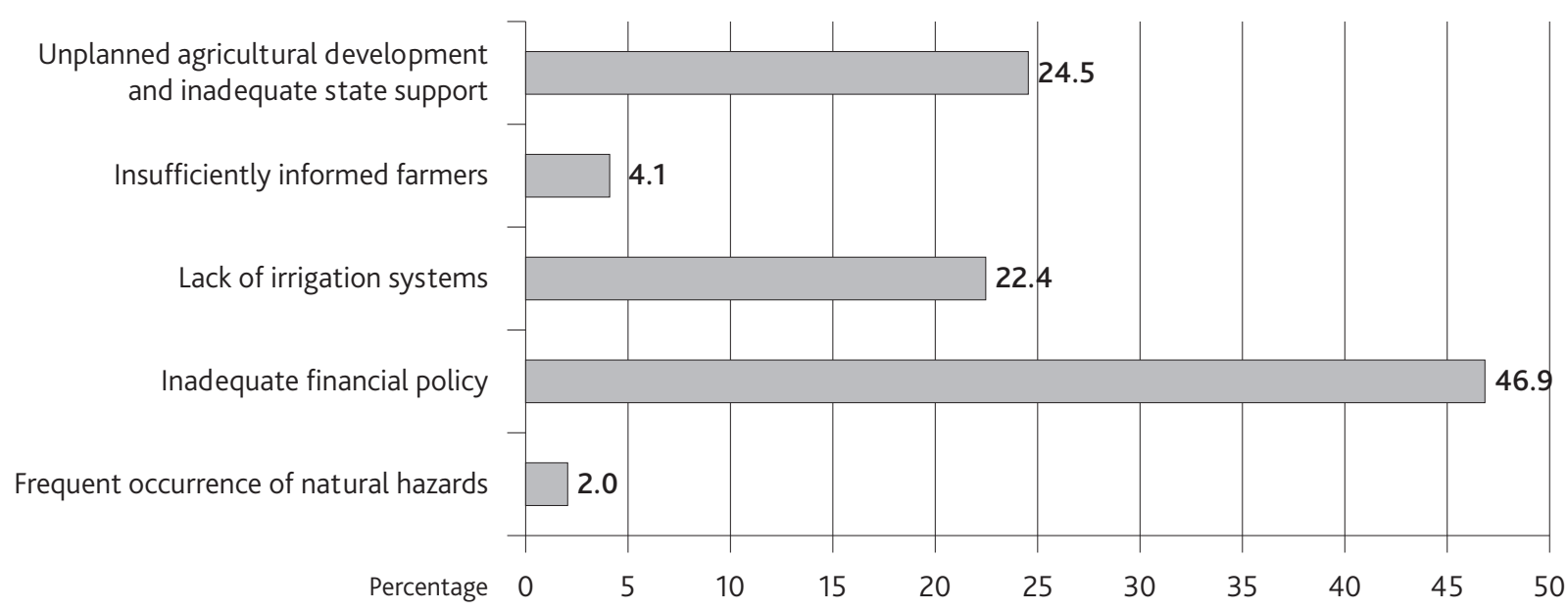

Figure 3. Main problems in agriculture in the region of research

frost, hale, strong winds, and incidence of plant diseases), and the fact that individuals in agriculture are insufficiently informed or competent (Figure 3).

\section{Occurrence of drought and economic consequences of drought periods}

For the region covered by the research, occurrence of drought is a very frequent natural hazard, which is in compliance with the obtained findings that almost all of the farmers included in the survey suffered a drought period (97.2\%). The year 2012 was rated as the worst year for agriculture. The respondents state that consequences of drought that occurred in 2012 were felt in 2013 as a lack of funds for investment into agricultural production. According to the respondents, the average length of drought periods was 4 months. The gravest consequences of the drought periods were reflected in crop yield. In 2012, according to the replies of the local farmers, the crop yield declined by as much as $52.84 \%$ (minimum decrease of $10 \%$, and maximum of $80 \%$ ), while the agricultural firms had a decrease in crop yield of $34 \%$ (minimum $20 \%$, and maximum 55\%). Apart from the reduced yield, the local agricultural population stated increase in irrigation costs, higher costs of working on dry and hard soil, and occurrence of plant diseases (fungi on corn that cause incidence of aflatoxin) as consequences of drought periods.

Corn and soy were most severely affected by the occurrence of drought. Taking into consideration the fact that Vojvodina is dominant in production of corn (58\%) and soy (94\%) in comparison with the whole territory of Serbia (Executive Council of Vojvodina, 2006), the drastic fall in crop yield in the drought period of 2012 had influence on the total national economy especially on income from export of agricultural produce that creates foundation for agricultural growth and development of agriculture in Vojvodina and in Serbia in general.
As for the amount of information the farmers have on occurrences that cause drought and drought periods, majority of them consider that drought is a consequence of climate change, i.e. global warming (59.2\%) while $18.3 \%$ of the respondents consider that they are not educated enough to give an answer to that question. In the researched region $60.5 \%$ of the respondents think that drought is caused by heat waves, $14 \%$ are of the opinion that drought occurs as a result of water shortage. A total of $25.6 \%$ of the interviewed persons consider that drought is a consequence of shifting influence of both these factors, i.e. that heat waves boost evapotranspiration and then plants structure lose water as a result of evaporation of water from plants' surface, soil, as well as through physiological process of transpiration. In the conditions where both factors are present the respondents think that intensity and duration of drought periods are extended. Agricultural stakeholder representatives $(71.4 \%)$ consider that drought is caused by water shortage.

\section{Water management and sustainability of agricultural production}

Majority of respondents do not irrigate their agricultural land $(65.3 \%)$. The individuals who do irrigate $(32.7 \%)$ mainly use water from wells or canals in their surroundings. As many as $57.1 \%$ of the farmers do not have irrigation canals while $36.7 \%$ of those who do have irrigation canals say that the canals are not functional or they are outdated and dry in the summer season. It can be concluded that the present situation in irrigation, observed through the total number of irrigation systems, is not on a satisfactory level, neither by its scope, nor by its equipment, the level of use related to water capacity of Vojvodina, or the needs of agriculture. Majority of the respondents do not make any additional financial investment in irrigation, and in their opinion investment from personal income would not be financially viable or feasible. 


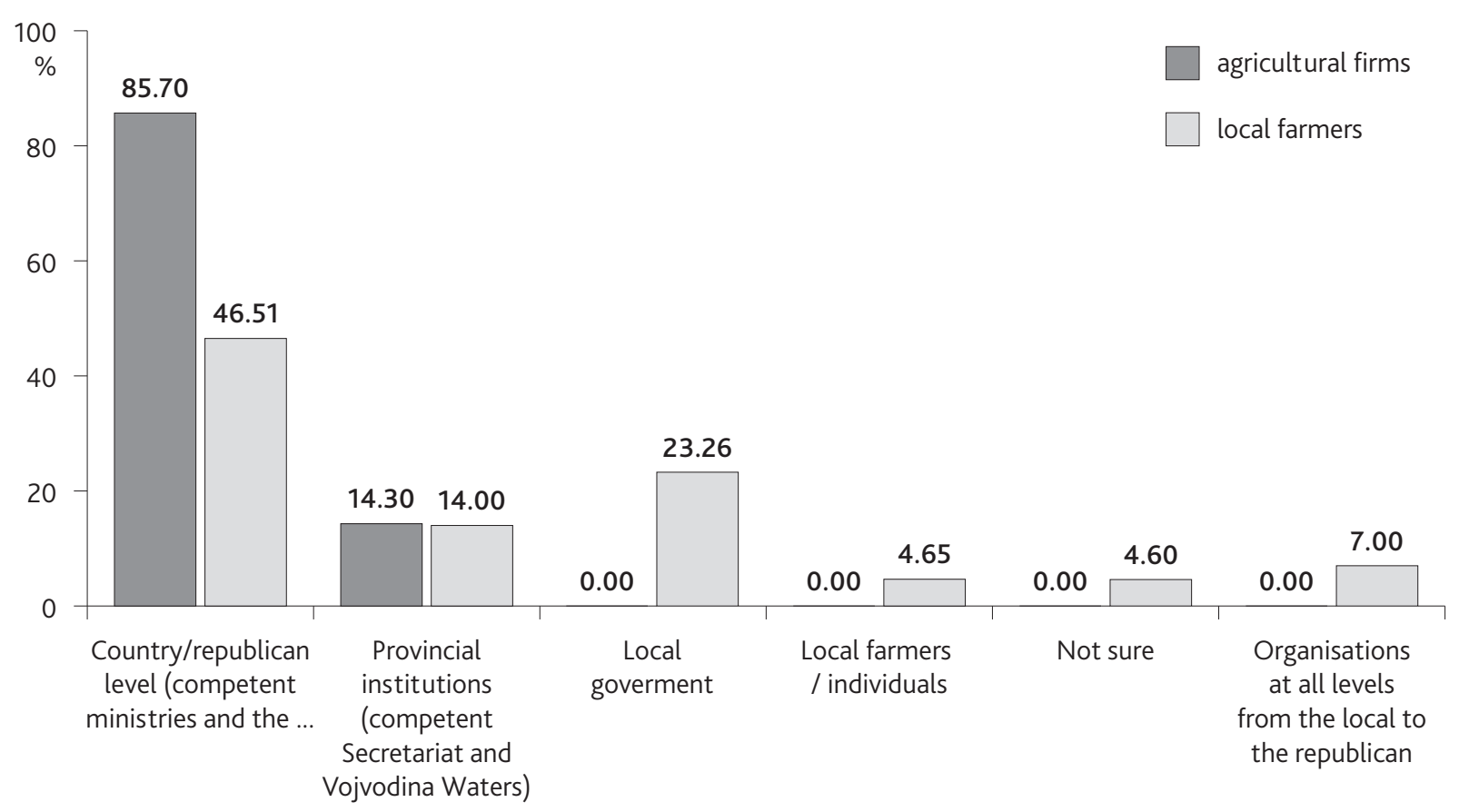

Figure 4. Respondents' opinions on person/institution responsible for improving irrigation system

As the answer to the question who should be responsible for improving the irrigation system in the region of research, majority of the farmers consider that it should be responsible institutions and government departments in charge on national level (46.5\%). A total of $23.3 \%$ of the respondents are of the opinion that the person in charge should be appointed within local community management while $14 \%$ believe that responsibility for improvement of irrigation system should be in the hands of the institutions in charge and departments on the Vojvodina Province level. It is interesting to note that a few respondents consider that it is not sufficient to establish one person or body in charge, but it has to be a synchronized system involving more subjects on all levels from local to national importance ( $7 \%)$. Majority of the agricultural firm representatives consider that the institution in charge should be defined on the level of the Republic of Serbia either within Ministry of agriculture, forestry and water management or within Republic hydrometeorology department (85.7\%) while $14.3 \%$ hold opinion that responsible body should be organized on the province level. In case there is a person or body responsible for irrigation system improvement, majority of the respondents, both farmers and representatives of agricultural firms, would be willing to cooperate with them (88\%) (Figure 4).

\section{Prediction and adaptive strategies in water management}

Drought hazard prediction/forecast may provide valuable data for a number of sectors of the society and economy, as well as to support development of optimal strategy planning for alleviating impacts of drought periods. However, majority of the farmers $(62.8 \%)$ are of the opinion that it is impossible to predict occurrence of drought periods, while the agricultural firm representatives were not sure whether such prediction of this natural hazard was possible (57.1\%). Although the respondents were familiar with climate and meteorology forecast of drought, they consider such forecast as unreliable and insufficiently precise (Figure 5).

Majority of the local farmers regard that Hydrometeorology Department of Serbia does not have sufficient amount of continuous weather data series on specific weather elements (temperature, precipitation, evapotranspiration) that could provide precise forecast of drought periods in future. Therefore, in order to provide sustainability of production, both agricultural population and agricultural firms use shortterm and mid-term methods of adapting to new climate conditions. Primarily this regards the following: change in the time of field works, in sowing density, biological protection methods, and change in method of soil treatment (short-term methods) and soil fertility improvement and selection of hybrid seeds with shorter vegetation period that are also more resistant to drought (mid-term methods). Possibility of establishing sustainable production in the new aggravated climate conditions depends on the local farmers' training and on the financial assets available. Unfortunately of all the respondents only the agricultural business believe they are prepared for agrarian adaptation, while as many as $43.2 \%$ of the local farmers regard they would not be able to adapt in case of aggravation of the current climate conditions. 


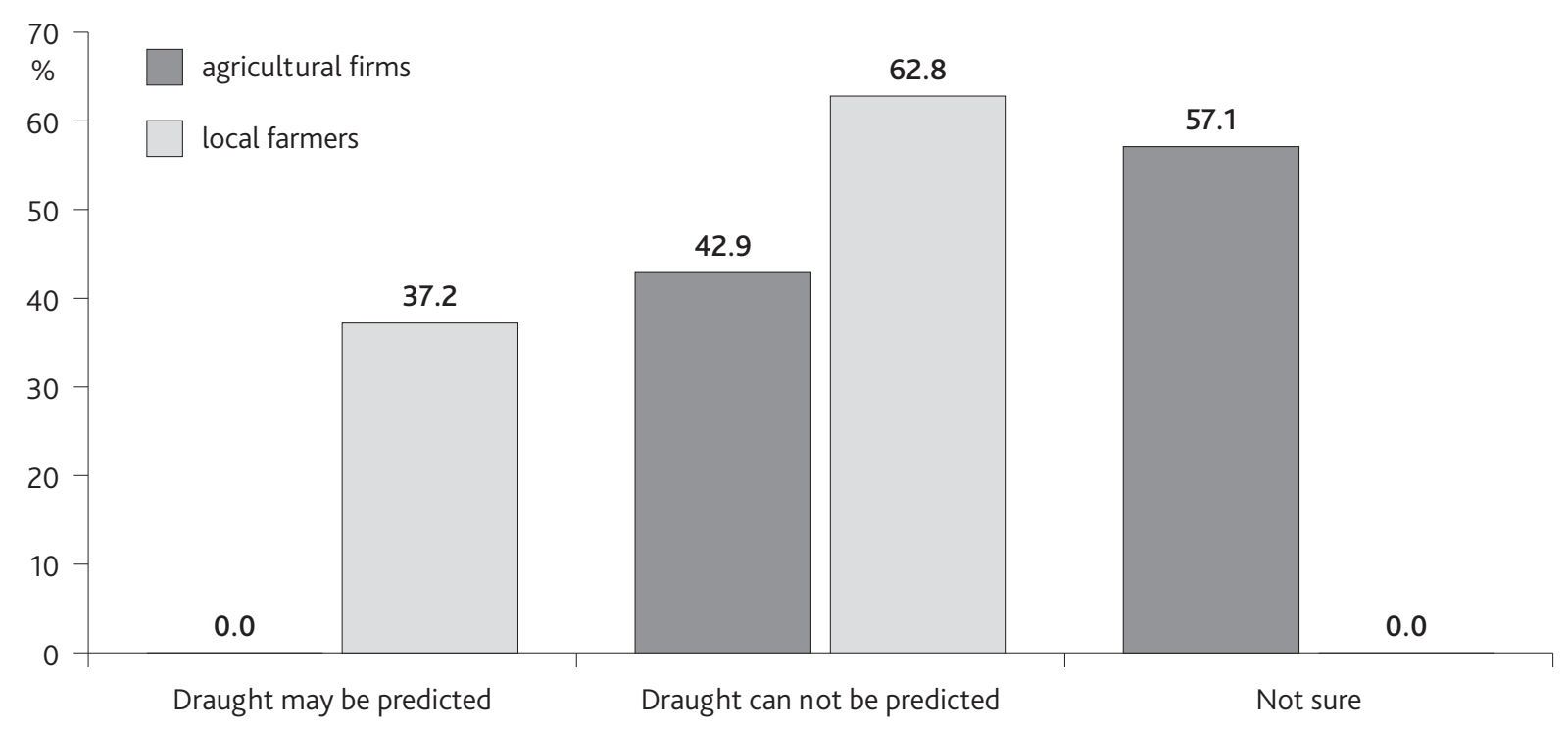

Figure 5. Can occurrence of draught be predicted?

Majority of individuals in agriculture (41.9\%) and firms (100\%) would be prepared to take out loans for irrigation, but both groups state that they have insufficient information on current government plans for loans for irrigation systems.

Necessary assistance for alleviation of adverse drought consequences includes subsidies for irrigation, improvement and reconstruction of the existing irrigation systems; organized and planned state management of agrarian policy; creating precise methods of forecast of drought periods and timely informing agricultural population and agricultural firms.

\section{Conclusion}

Based on the research main issues in agriculture have been identified, and they mainly concern inadequate assistance and support from the government to agriculture development, absence of a long-term plan of management and development of agricultural business, inadequate agrarian policy, as well as inadequate pricing policy, which refers to high costs of agricultural production, insecure placement and low purchase prices. Apart from predominantly political and financial problems, farmers consider that conditions for agricultural production are also inadequate. This refers to the following: a) absence of adequate irrigation systems, i.e. the fact that the existing ones are outdated, neglected, and not functional; b) absence of adequate methodology of forecast of natural hazards, while such methodologies could help in prevention and reduction of damage caused by such hazards. The respondents listed drought, frost, hale and strong storm winds as the major natural hazards.

For the researched region occurrence of drought is a very frequent natural hazard, which is in compli- ance with the fact that almost all of the respondents suffered a drought period (97.2\%). Major consequences from drought were registered in 2012. However, the farmers felt consequences of that drought period in the following year, 2013, as the drought disabled normal and continuous agricultural production. Decrease of yield directly affected reduction in financial assets available for investment in further agricultural production, thus the drought period harmed continuity of normal agricultural production. Apart from the reduced income, agricultural population faced an increase of all input costs of agricultural production, such as additional financial outcome for irrigation, fertilizers, soil preparation and working of dry and hard soil. Besides financial costs, in the last drought period of 2012, diseases appeared on plants (fungi on corn that cause occurrence of aflatoxin) that affected the total agricultural export, as well as reduction in prices of agricultural produce.

Majority of respondents hold the opinion that drought is a consequence of global climate changes. However as many as $18.3 \%$ of the respondents are not informed nor educated enough to answer the question what factors cause occurrence of drought. From these answers we can conclude that further development of agriculture of the researched region requires education of rural population and providing them with counseling and assistance concerning agrarian adaptation during drought periods in order to maintain sustainable continuous agricultural production.

As far as possibility for irrigation of agricultural land is concerned, majority of the respondents are not in position to irrigate their agricultural land. More than half of the surveyed farmers do not have irrigation canals while $36.7 \%$ of those who do have irrigation canals say that the canals are outdated, not functional and dry in 
the summer season. It can be concluded that the present situation regarding irrigation viewed through the total number of irrigation systems is below satisfactory level in terms of scope, technical equipment, and usage extent compared to the water capacity of Vojvodina and needs of agriculture.

All respondents say that for overcoming major obstacles for agriculture in the researched region it is necessary to appoint persons in charge for professional and sustainable management of agricultural development (the Extension Officers). According to the research findings, the respondents believe that appointing such a person in charge on the national level would be the most efficient system of managing agrarian policy and further development of agriculture.

As for the methods of prediction of occurrence of drought periods, most of the farmers consider that it is impossible to forecast occurrence of drought periods, while the representatives of the agricultural firms are not sure about the possibility of prediction of this natural hazard. Although the respondents are familiar with climate and meteorological forecast of drought periods, they consider such forecast unhelpful and rate them as unreliable and insufficiently precise.

Forecast of drought hazard can provide precious data for a number of social and economic sectors, as well as to support development of more optimal planning of strategies for alleviating consequences of drought periods. Preparation for future drought periods, by means of developing optimal way of land use and water management should be the main goal of spatial planning in order to minimize consequences and damage caused by occurrence of drought. The most efficient adaptive strategies for prevention of drought period occurrence are change in the way of using agricultural land, reconstruction and development of the irrigation system, as well as selection of new sorts and hybrids that are drought-resistant and capable of using the available water more efficiently. However, these strategies require substantial financial investment and long-term implementation.

\section{Acknowledgement}

The research is financially supported by IPA project "Water shortage hazard and adaptive water management strategies in the Hungarian-Serbian cross-border region" (WAHASTRAT) HUSRB/1203/121/130

\section{References}

Bollig C., Feller U., 2014. Impacts of drought stress on water relations and carbon assimilation in grassland species at different altitudes. Agriculture, Ecosystems and Environment 188, 212-220.
Božić M., Nikolić G., Stević D., Životić Lj., Dragović S., 2007. Drought mitigation by means of irrigation in maize. Vodoprivreda, 39, (5-6), 357-365.

Comfort, L.K., Kapucu, N., 2004. Inter-organizational coordination in extreme events: the World Trade Center Attack, September 11, 2001. Natural Hazards 39, 309-327.

Dale, R.F., Shaw, R.H., 1965. Effect on corn yields of moisture stress and stand at two different fertility levels. Agron. J. 57, 475-479.

Holbeche, L., 2006. Understanding Change: Theory, Implementation and Success. Elsevier Science Ltd., Oxford, UK.

Hunt D. E., Svoboda M., Wardlow B., Hubbard K., Hayes M., Arkebauer T., 2014. Monitoring the effects of rapid onset of drought on non-irrigated maize with agronomic data and climate-based drought indices. Agricultural and Forest Meteorology 191, 1-11.

Hurlimann A., Dolnicar S., 2011. Voluntary relocation - An exploration of Australian attitudes in the context of drought, recycled and desalinated water. Global Environmental Change, 21,3,1084-1094.

Intergovernmental Panel on Climate Change (IPCC), 2010. World Climate Report on Global Drought Patterns. http://www.worldclimatereoprt.com/index.php/2010/02/24/update-on-global-droughtpatterns-ipcc (accessed 15.05.12.).

Ivanović M., Čapelja V., Radojčić S., Popov R., Nastasić A., 2008. Maize in 2007 - lessons for a dry year . Zbornik radova Instituta za ratarstvo i povrtarstvo, 45, 2, 61-65.

Karami, E., Keshavarz, M., 2009. Sociology of sustainable agriculture. In: Lichtfouse, E. (Ed.), Sustainable Agriculture Reviews, 3, 19-40.

Keshavarz M., Karami E., 2013. Institutional adaptation to drought: The case of Fars Agricultural Organization. Journal of Environmental Management 127, 61-68.

Keshavarz, M., Karami, E., Vanclay, F., 2013. The social experience of drought in rural Iran. Land Use Policy 30, 120-129.

Mihailović D.Lalić B., Arsenić I., 200o. Drought - adverse weather phenomena in agriculture. Biljni lekar, 28, 5, 347-354.

Milanović M., Gocić M., Trajković S., 2012. Analysis of modified Torntvajt-ovog humidity index in Serbia for the period since 1980. to 2010. Zbornik radova Građevinsko-arhitektonskog fakulteta, Niš, 27, 29-36.

Jovanović, M., Pavić, D., Minučer, M., Stankov, U., Pantelić, M., Armenski, T., Dolinaj, D., Popov, S., Ćosić, Đ., Popović, Lj., Frank, A., Crnojević, V. 2013. Water shortage and drought monitoring in Bačka region (Vojvodina, North Serbia) - setting-up 
measurement stations network, Geographica Pannonica, 17 (4), 114-124.

Nikolova, N., Alieva, G., Voislavova, I., 2012. Drought Periods in Non-Mountainous Part of South Bulgaria on the Background of Climate Change, Geographica Pannonica, 16 (1), 18-25.

Næss, L.O., Bang, G., Eriksen, S., Vevatne, J., 2005. Institutional adaptation to climate change: flood responses at the municipal level in Norway. Global Environmental Change 15, 125-138.

O’Brien, G., O'Keefe, P., Rose, J., Wisner, B., 2006. Climate change and disaster management. Disasters 30 (1), 64-80.

Rajić M., Grujić D., 2013. Drought periods growing season in North Banat. Letopis naučnih radova Poljoprivrednog fakulteta, 37, 1, 36-44.

Rajić M., Štula S., 2007. Climate change and drought in South Backa. Letopis naučnih radova Poljoprivrednog fakulteta, 31, 1, 80-89.

Sepulcre-Canto G., Vogt J., Arboleda A., Antofie T., 2014. Assessment of the EUMETSAT LSA-SAF evapotranspiration product for drought monitoring in Europe. International Journal of Applied Earth Observation and Geoinformation, 30, 190-202
Starik, M., Rands, G.P., 1995. Weaving an integrated web e multilevel and multisystem perspectives of ecologically sustainable organizations. Academy of Management Review 20 (4), 908-935.

Svoboda, M., Lecomte, D., Hayes, M., Heim, R., Gleason, K., Angel, J., Rippey, B., Tin-ker, R., Palecki, M., Stooksbury, D., Miskus, D., Stephens, S., 2002. The droughtmonitor. Bull. Am. Meteorol. Soc. 83 (8), 1181-119o.

Vojvodina Chamber of Commerce, 2012. Information about the current state of agricultural production. Association of agriculture, food industry and water management group registered family farms, Novi Sad.

Wilbanks, T.J., 2002. Geographic scaling issues in integrated assessments of climate change. Integrated Assessment 3, 100-114.

Wilhite, D., 2005. Droughts and Water Crises: Science, Technology, and Management Issues. Taylor and Francis Group, Boca Raton.

Wilhite, D.A., Glantz, M.H., 1985. Understanding the drought phenomenon: the roleof definitions. $\mathrm{Wa}$ ter Int. 10, 111-120. 